\title{
EFFECT OF INCUBATION AND LIMING ON THE PHOSPHORUS FRACTIONS IN SOIL
}

\author{
Armi KaILA \\ University of Helsinki, Department of Agricultural Chemistry
}

Received May 24, 1961

There exists in the soil a dynamic equilibrium between the forms of phosphorus. RATHJE (12) emphasized the importance of the equilibrium between hydroxylapatite and sesquioxide phosphates which largely depends on the $\mathrm{pH}$ of soil. There is also an equilibrium between the organic and inorganic forms of phosphorus controlled e.g. by the activity of microorganisms. Phosphorus added to the soil in fertilizers may disturb these equilibriums, yet, at a slower or faster rate, it will turn over to that form which is most stable under the conditions of the particular soil. The profitable effect of lime on acid soils is partly attributed to the improvement of phosphorus conditions either through the mineralization of organic phosphorus compounds or through the rendering phosphorus bound by iron and aluminium complexes more available $(1,6,13)$. Which of these ways is the more important one in different cases, has not yet been indisputably demonstrated.

The laboratory experiments described in this paper were carried out in order to study the changes in the soil phosphorus resulted from a prolonged incubation, and the role lime is playing in these changes. An attempt was also made to trace the fate of fertilizer phosphorus in these incubation experiments.

\section{Material and methods}

The soil samples were collected from the surface inch of two field trials in which superphosphate and hyperphosphate were compared (8). In the trial on a loam soil superphosphate had been annually applied as a surface dressing at the rate of $200 \mathrm{~kg} /$ ha for three years, in the trial on a silt soil this treatment was repeated in four years. The application of $2000 \mathrm{~kg} / \mathrm{ha}$ of hyperphosphate occurred in the trial on the loam soil four years, and in the trial on the silt soil five years before the sampling.

Samples from all the four replicate plots were separately incubated and analyzed. $100 \mathrm{~g}$ of air-dry and ground soil was weighed into a glass jar, moistened with distilled water to the field capacity, and incubated at about $20^{\circ} \mathrm{C}$ for seven months. Before 
the moistening, $1 \mathrm{~g}$ of calcium carbonate was added to a second set of samples and thoroughly mixed. At the end of the incubation period the samples were air-dried and ground.

The $\mathrm{pH}$-values refer to $1: 2.5$ water suspension.

$\mathrm{P}$ soluble in $0.03 \mathrm{~N} \mathrm{NH}_{4} \mathrm{~F}-0.025 \mathrm{~N} \mathrm{HCl}$ was extracted in the ratio of 1:10 by shaking for one minute. The acetic acid soluble $\mathrm{P}$ was determined by using $0.5 \mathrm{~N}$ acid in the ratio of 1:10, the shaking period being half an hour.

Phosphorus fractionation was performed by the method introduced by CHANG and JACKSON (3). Instead of neutral $\mathrm{NH}_{4} \mathrm{~F}$-solution a slightly alkaline extractant recommended by FifE (5) was used.

For the determination of organic phosphorus two methods were employed. In the acid-alkali extraction procedure $2 \mathrm{~g}$ of soil was treated with $50 \mathrm{ml}$ of $4 \mathrm{~N} \mathrm{H}_{2} \mathrm{SO}_{4}$ in $100 \mathrm{ml}$ Erlenmeyer flask for 18 hours with occasional stirring during the first hour. After filtration and washing with distilled water to give a leachate of $200 \mathrm{ml}$ the filter paper with soil was transferred to a $300 \mathrm{ml}$ Erlenmeyer flask, $200 \mathrm{ml}$ of $0.5 \mathrm{~N} \mathrm{NaOH}$ was added, and the suspension was left to stand over night with occasional stirring during the first two hours. The thoroughly mixed suspension was centrifuged, or poured into a high glass, and on the following day the clear supernatant extract was analyzed. For the determination of the inorganic P extracted, equal amounts of the acid extract and the alkaline extract were mixed, and the dark organic matter precipitated removed by filtering or centrifuging. The destruction of organic matter for the determination of total $\mathrm{P}$ extracted was performed either by dry or wet combustion. In the former case, $10 \mathrm{ml}$ of both extracts were mixed and evaporated to dryness with $3 \mathrm{ml}$ of $2 \mathrm{~N} \mathrm{NaNO}_{3}$, ignited at $550^{\circ} \mathrm{C}$, and heated on a boiling water bath for at least two hours in $21 \mathrm{ml}$ of $1 \mathrm{~N} \mathrm{H}_{2} \mathrm{SO}_{4}$. The wet combustion was performed with the aid of a mixture containing two parts of $70 \%$ perchloric acid and one part of concentrated sulphuric acid. The difference of the total and inorganic $\mathrm{P}$ extracted represents the organic $\mathrm{P}$.

In the ignition method $2 \mathrm{~g}$ of air-dry soil was ignited for 1 hour at $550^{\circ} \mathrm{C}$. Both the ignited residue and a $2 \mathrm{~g}$ lot of untreated soil were then extracted with $200 \mathrm{ml}$ of $0.2 \mathrm{~N} \mathrm{H}_{2} \mathrm{SO}_{4}$ for two hours. The difference between the $\mathrm{P}$ extracted from the ignited and the unignited soil is taken to represent the organic $\mathrm{P}$ of the soil.

Since the acid-alkali extraction method probably gives too low results, while the values obtained by the ignition method are likely to be too high, an average of the figures was supposed to be the most reliable estimation of soil organic P.

\section{Results}

The effect of incubation and liming on the reaction of the experimental soils is illustrated by the data in Table 1 . Both soils are slightly acid, the loam soil somewhat more acid than the silt soil. A marked drop in the $\mathrm{pH}$-values is caused by incubation, while liming has been able to increase the $\mathrm{pH}$-values so much that even at the end of the incubation the soils are neutral.

The $\mathrm{P}$ test values, also recorded in Table 1, reveal the effect of phosphate fertilizers in the degree that could be expected: the treatment with superphosphate is 
Table. 1. $\mathrm{pH}$ and phosphorus test values in the original and incubated soil samples

\begin{tabular}{|c|c|c|c|c|c|c|}
\hline & \multicolumn{3}{|c|}{ Loam soil } & \multicolumn{3}{|c|}{ Silt soil } \\
\hline & 0 & Super & Hyper & 0 & Super & Hyper \\
\hline Original & 5.7 & 5.6 & 5.7 & 5.9 & 5.7 & 5.9 \\
\hline Incubated & 5.0 & 5.0 & 5.1 & 5.3 & 5.1 & 5.3 \\
\hline Incubated with lime & 7.0 & 7.2 & 7.2 & 7.3 & 7.3 & 7.3 \\
\hline L.S.D. at $5 \%$ & \multicolumn{3}{|c|}{0.1} & \multicolumn{3}{|c|}{0.1} \\
\hline
\end{tabular}

P ppm extracted by $0.03 \mathrm{~N} \mathrm{NH}_{4} \mathrm{~F}-0.025 \mathrm{~N} \mathrm{HCl}$

\begin{tabular}{|c|c|c|c|c|c|c|}
\hline Original & 22 & 62 & 33 & 14 & 39 & 23 \\
\hline Incubated & 36 & 80 & 59 & 24 & 57 & 37 \\
\hline Incubated with lime & 32 & 65 & 41 & 25 & 51 & 34 \\
\hline \multirow[t]{2}{*}{ L.S.D. at $5 \%$} & & 8 & & & 9 & \\
\hline & \multicolumn{6}{|c|}{ P ppm extracted by $0.5 \mathrm{~N}$ acetic acid } \\
\hline Original & 8 & 16 & 96 & 12 & 17 & 101 \\
\hline Incubated & 8 & 16 & 85 & 12 & 18 & 99 \\
\hline Incubated with lime & 8 & 20 & 55 & 12 & 24 & 69 \\
\hline L.S.D. at $5 \%$ & \multicolumn{3}{|c|}{23} & & 29 & \\
\hline
\end{tabular}

not apparent in the acetic acid values, while it is evident from the results of the acid fluoride extraction. The latter numbers also show the treatment with hyperphosphate, although to a far less degree than do the corresponding figures for the acetic acid soluble P. The incubation has increased the acid fluoride soluble $\mathrm{P}$ in all the samples, but the treatment with lime has, particularly in the loam soil, reduced this increase. The amount of acetic acid soluble $\mathrm{P}$ has not been changed by the incubation. The fact that acetic acid has not dissolved more $\mathrm{P}$ from the limed samples may be attributed to the neutralizing effect of lime on the acid: the $\mathrm{pH}$ of the extract of the limed samples was about 3.5 while that of the unlimed samples kept at about $\mathrm{pH} 3.1$.

On the basis of these test values it might be concluded that the incubation has probably somewhat improved the availability of phosphorus in these samples. No positive effect of lime is apparent.

The results of the $\mathrm{P}$ fractionation give a more thorough picture of the changes brought about by the incubation. The data obtained for the samples from the untreated plots are reported in Table 2. In both soils the incubation has caused an increase in the inorganic P extracted by ammonium fluoride and sodium hydroxide. No changes in the amount of acid soluble $\mathrm{P}$ has occurred. The increase in the inorganic Pextracted is most likely due to the mineralization of organic P, since a significant decrease in this form is found. The effect of lime is most evident in the reducing of the accumulation of the mineralized $\mathrm{P}$ as the alkali-soluble form. Only in the loam soil it has, to some degree, increased the amount of acid-soluble $\mathrm{P}$, in the silt 
Table 2. $\mathrm{P}$ fractions in the original and incubated samples of untreated soil (Expressed as $\mathrm{P}$ ppm)

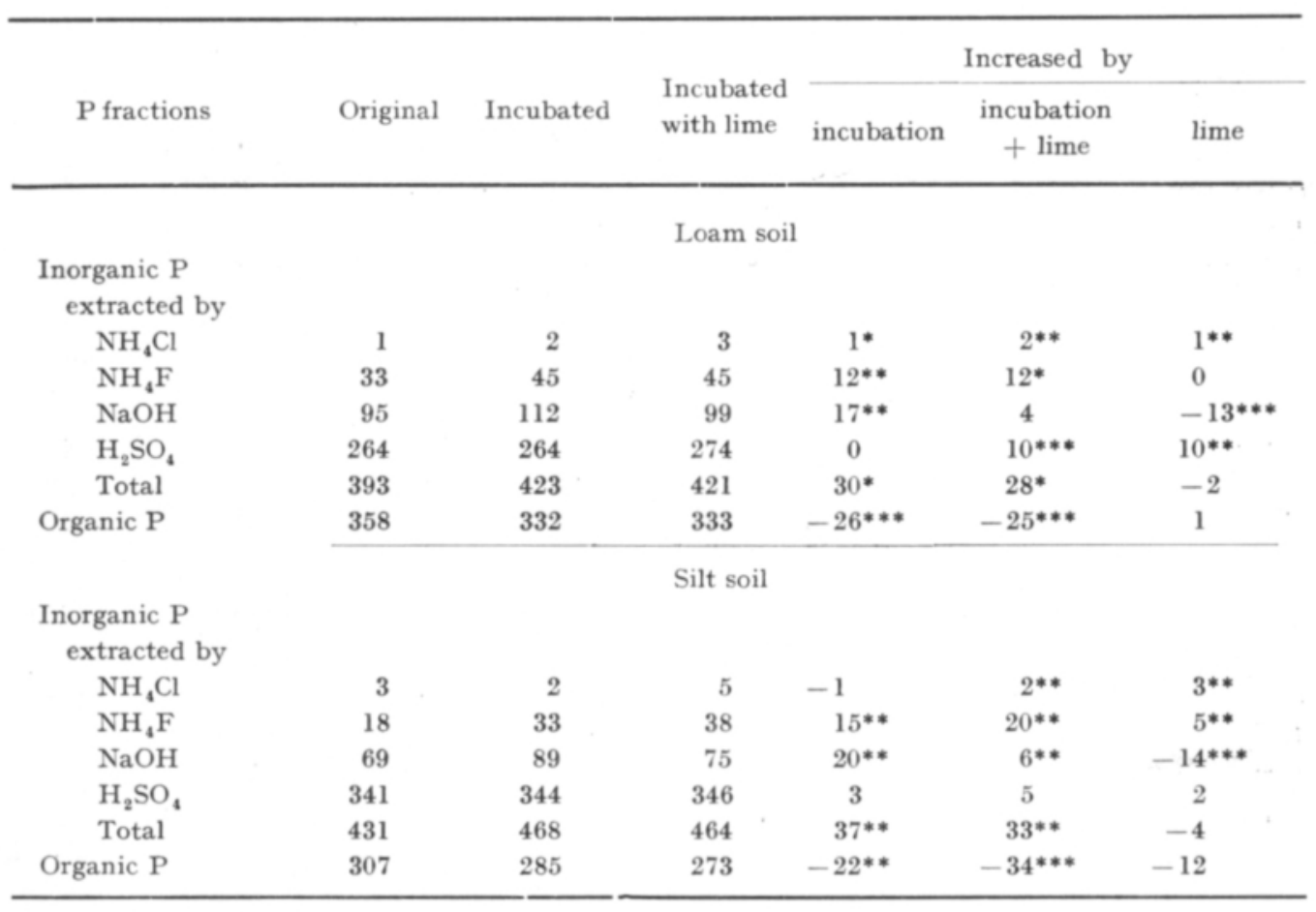

soil a slight increase in the fluoride-soluble fraction may be detected. It is of interest to find out that lime did not exert any effect on the mineralization of organic $\mathrm{P}$ in these soils.

The $\mathrm{P}$ fractions of the soil from the plots treated with superphosphate (Table 3) have undergone changes similar to those found in the untreated samples. Only the effect of lime on the increase of the acid-soluble fraction and the decrease in the alkali-soluble fraction seems to be more marked than in the untreated soils.

In the results obtained for the samples treated with hyperphosphate (Table 4) some new features may be observed. The incubation has brought about in both soils a marked decrease in the acid-soluble $\mathrm{P}$ with a corresponding higher increase in the fluoride- and alkali-soluble fractions. Apparently, lime has prevented the turning over of acid-soluble $\mathrm{P}$ to the alkali-soluble form, and the organic $\mathrm{P}$ mineralized is in the limed samples mainly accumulated in the fraction which is extracted by ammonium fluoride or in the acid soluble form.

Even in the samples from the plots treated with superphosphate or hyperphosphate, the effect of lime on the mineralization of organic phosphorus appears to be negligible.

In all the cases incubation with lime has increased the low amount of $\mathbf{P}$ extracted by the first treatment, or by ammonium chloride. In the loam soil, also incubation without lime has improved the solubility of $\mathrm{P}$ in this extractant.

The closest estimate of the changes in the fertilizer phosphorus which may be obtained on the basis of this material, is the difference between the corresponding 
Table 3. P fractions in the original and incubated samples of soil treated with superphosphate (Expressed as P ppm)

\begin{tabular}{|c|c|c|c|c|c|c|}
\hline \multirow[b]{2}{*}{$\mathrm{P}$ fractions } & \multirow[b]{2}{*}{ Original } & \multirow[b]{2}{*}{ Incubated } & \multirow{2}{*}{$\begin{array}{l}\text { Incubated } \\
\text { with lime }\end{array}$} & \multicolumn{3}{|c|}{ Increased by } \\
\hline & & & & incubation & $\begin{array}{l}\text { incubation } \\
+ \text { lime }\end{array}$ & lime \\
\hline & & & Loam soil & & & \\
\hline \multicolumn{7}{|c|}{$\begin{array}{l}\text { Inorganic } \mathrm{P} \\
\text { extracted by }\end{array}$} \\
\hline $\mathrm{NH}_{4} \mathrm{Cl}$ & 3 & 5 & 8 & $2 * *$ & $5^{*}$ & $3^{*}$ \\
\hline $\mathrm{NH}_{4} \mathrm{~F}$ & 91 & 103 & 105 & $12^{* *}$ & $14^{* *}$ & 2 \\
\hline $\mathrm{NaOH}$ & 138 & 157 & 136 & $19 * *$ & -2 & $-21 * *$ \\
\hline $\mathrm{H}_{2} \mathrm{SO}_{4}$ & 262 & 260 & 273 & -2 & 11 & $13^{* *}$ \\
\hline To al & 494 & 525 & 522 & $31^{*}$ & $28^{*}$ & -3 \\
\hline \multirow[t]{2}{*}{ Organic P } & 370 & 343 & 340 & $-27 * * *$ & $-30 * * *$ & -3 \\
\hline & & & Silt soil & & & \\
\hline \multicolumn{7}{|c|}{$\begin{array}{l}\text { Inorganic } P \\
\text { extracted by }\end{array}$} \\
\hline $\mathrm{NH}_{4} \mathrm{Cl}$ & 4 & 5 & 10 & 1 & $6 * *$ & $5 * * *$ \\
\hline $\mathrm{NH}_{4} \mathrm{~F}$ & 57 & 73 & 76 & $16 * *$ & $19 * * *$ & 3 \\
\hline $\mathrm{NaOH}$ & 110 & 132 & 110 & $22 * * *$ & 0 & $-22 * *$ \\
\hline $\mathrm{H}_{2} \mathrm{SO}_{4}$ & 349 & 344 & 355 & $-5^{*}$ & 6 & $11 * * *$ \\
\hline Total & 520 & 554 & 551 & $34 * * *$ & $31 * * *$ & -3 \\
\hline Organic $\mathrm{P}$ & 299 & 272 & 271 & $-27 *$ & $-28 * *$ & -1 \\
\hline
\end{tabular}

Table 4. $\mathrm{P}$ fractions in the original and incubated samples of soil treated with hyperphosphate (Expressed as $\mathrm{P}$ pmm)

\begin{tabular}{|c|c|c|c|c|c|c|}
\hline \multirow[b]{2}{*}{$\mathrm{P}$ fractions } & \multirow[b]{2}{*}{ Original } & \multirow[b]{2}{*}{ Incubated } & \multirow{2}{*}{$\begin{array}{l}\text { Incubated } \\
\text { with lime }\end{array}$} & \multicolumn{3}{|c|}{ Increased by } \\
\hline & & & & incubation & $\begin{array}{c}\text { incubation } \\
\text { lime }+\end{array}$ & lime \\
\hline & & & Loam soil & & & \\
\hline \multicolumn{7}{|c|}{$\begin{array}{l}\text { Inorganic } \mathrm{P} \\
\text { extracted by }\end{array}$} \\
\hline $\mathrm{NH}_{4} \mathrm{Cl}$ & 2 & 3 & 4 & $1 * * *$ & $2 *$ & 1 \\
\hline $\mathrm{NH}_{4} \mathrm{~F}$ & 54 & 82 & 66 & $28 * *$ & $12^{* *}$ & $-16^{*}$ \\
\hline $\mathrm{NaOH}$ & 118 & 139 & 111 & $21 * * *$ & $-7 * *$ & $-28 * *$ \\
\hline $\mathrm{H}_{2} \mathrm{SO}_{4}$ & 486 & 468 & 505 & $-18^{* *}$ & $19 *$ & $37 * * *$ \\
\hline Total & 660 & 692 & 686 & $32^{*}$ & $26 * * *$ & -6 \\
\hline \multirow[t]{2}{*}{ Organic $\mathrm{P}$} & 388 & 356 & 360 & $-32 * * *$ & $-28 * *$ & 4 \\
\hline & & & Silt soil & & & \\
\hline \multicolumn{7}{|c|}{$\begin{array}{l}\text { Inorganic } P \\
\text { extracted by }\end{array}$} \\
\hline $\mathrm{NH}_{4} \mathrm{Cl}$ & 3 & 4 & 6 & 1 & $3^{*}$ & $2 * *$ \\
\hline $\mathrm{NH}_{4} \mathrm{~F}$ & 35 & 54 & 54 & $19 * * *$ & $17 * *$ & -2 \\
\hline $\mathrm{NaOH}$ & 94 & 119 & 91 & $25 * * *$ & -3 & $-28 * * *$ \\
\hline $\mathrm{H}_{2} \mathrm{SO}_{4}$ & 538 & 515 & 539 & $-23^{* *}$ & 1 & $24 * * *$ \\
\hline Total & 670 & 692 & 688 & $22^{* *}$ & $18^{*}$ & -4 \\
\hline Organic $\mathrm{P}$ & 290 & 267 & 269 & $-23^{* *}$ & $-21 * *$ & 2 \\
\hline
\end{tabular}


results for the samples from the treated and untreated plots. The tracing of the fate of the applied phosphorus in this way is not theoretically sound, owing to the fact that the samples originated from field trials in which the uptake of phosphorus by plants was not equal from the treated and untreated plots. Yet, in the lack of anything better this approach may be employed to get some idea of the distribution of fertilizer phosphorus in these soils.

The differences in the various fractions of inorganic phosphorus in the samples treated with superphosphate and in the untreated samples are the following:

$\begin{array}{lrrrrrr}\begin{array}{l}\text { P ppm } \\ \text { extracted } \\ \text { by }\end{array} & \text { Original } & \begin{array}{c}\text { Loam soil } \\ \text { Incubated }\end{array} & \begin{array}{c}\text { Incubated } \\ \text { with lime }\end{array} & \text { Original } & \begin{array}{c}\text { Silt soil } \\ \text { Incubated }\end{array} & \begin{array}{r}\text { Incubated } \\ \text { with lime }\end{array} \\ \quad \mathrm{NH}_{4} \mathrm{Cl} & 2 & 3 & 5 & 1 & 3 & 5 \\ \mathrm{NH}_{4} \mathrm{~F} & 58 & 58 & 60 & 39 & 40 & 38 \\ \mathrm{NaOH} & 43 & 45 & 37 & 41 & 43 & 35 \\ \mathrm{H}_{2} \mathrm{SO}_{4} & 0 & 0 & 0 & 8 & 0 & 9\end{array}$

In the unincubated samples of the loam soil the treatment of superphosphate seems to have increased the fractions soluble in ammonium fluoride and sodium hydroxide. The incubation has not caused any changes in the amount of these fractions, and this holds true also with the incubation with lime, since the decrease in the alkali soluble fraction is not statistically significant. The "superphosphate-phosphorus» in the silt soil also accumulated in the fluoride- and alkali-soluble fractions, and no changes in these forms can be detected due to the incubation or the incubation with lime. In this soil the incubation seems to have decreased the low amount of acid-soluble phosphorus which is assumed to originate from the treatment with superphosphate. Incubation with lime has prevented this decrease. The easily soluble part of "superphosphate- phosphorus» was increased in both soils as a result of the incubation with lime.

The corresponding differences in the values for the samples from the plots treated with hyperphosphate and from the untreated plots are the following:

\begin{tabular}{|c|c|c|c|c|c|c|}
\hline $\begin{array}{l}\text { P ppm } \\
\text { extracted } \\
\text { by }\end{array}$ & Original & $\begin{array}{l}\text { Loam soil } \\
\text { Incubated }\end{array}$ & $\begin{array}{l}\text { Incubated } \\
\text { with lime }\end{array}$ & Original & $\begin{array}{c}\text { Silt soil } \\
\text { Incubated }\end{array}$ & $\begin{array}{l}\text { Incubated } \\
\text { with lime }\end{array}$ \\
\hline $\mathrm{NH}_{4} \mathrm{Cl}$ & 1 & 1 & 1 & 0 & 2 & 1 \\
\hline $\mathrm{NH}_{4} \mathrm{~F}$ & 21 & 37 & 21 & 17 & 21 & 16 \\
\hline $\mathrm{NaOH}$ & 23 & 27 & 12 & 25 & 30 & 16 \\
\hline $\mathrm{H}_{2} \mathrm{SO}_{4}$ & 222 & 204 & 231 & 197 & 171 & 193 \\
\hline
\end{tabular}

As could be expected, in both soils the hyperphosphate phosphorus is accumulated mainly in the acid-soluble fraction. Yet, there seems to be some nfertilizer phosphorus" also in the ammonium fluoride-soluble and the alkali-soluble fractions. Provided, these differences in the phosphorus content of the soil treated with hyperphosphate and the untreated soil really represent fertilizer phosphorus, this would mean that during the four or five years of contact with the soil in the field, some apatite has been disolved. 
Incubation has brought about a significant decrease in the acid-soluble wfertilizer phosphorus» with an increase in the values for the fluoride-soluble phosphorus. The presence of lime has prevented this reaction, and there also seems to be less "fertilizer phosphorus» in the alkali-soluble fraction. In every case, results of this kind of calculation must be treated with caution.

\section{Discussion}

In the present incubation experiments liming did not exert any effect on the mineralization of organic phosphorus: the turning over of organic phosphorus into inorganic forms was equally high in samples incubated with or without lime. One possible reason for this result may be found in the fact that neither of the experimental soils was very acid, the $\mathrm{pH}$ values being 5.7 and 5.9 respectively. The incubation increased the acidity to $\mathrm{pH} 5.0$ and 5.3, but incubation with lime could keep the $\mathrm{pH}$ values as high as 7.0 and 7.3 , respectively.

These differences in the reaction and calcium carbonate content of the samples incubated without or with lime were reflected in the changes observed in the fractions of inorganic phosphorus. In the unlimed samples the phosphorus released from the organic compounds apparently was accumulated in the fractions extracted by ammonium fluoride and sodium hydroxide, or fractions which are supposed to represent aluminium bound and iron bound phosphorus, respectively. Yet, the former fraction may also contain dicalcium phosphate (9), and the latter one phosphorus disssolved from aluminium complex and adsorbed by iron oxide (2). When the samples were incubated with lime, the mineralized phosphorus mainly tended to enhance the ammonium-fluoride soluble fraction. In one case also an increase in the acidsoluble fraction was detected. This holds true both in regard to the samples from untreated plots and from the plots treated with superphosphate.

In the samples originating from the plots to which hyperphosphate was applied some years before the sampling, the incubation with its increase in the acidity of the soil resulted in a considerable increase in the ammoniumfluoride and sodium hydroxide soluble phosphorus accounted not only to the mineralisation of organic phosphorus but also to a marked decrease in the acid-soluble fraction. This suggests that a part of the apatite of the hyperphosphate was dissolved and turned over to fluorideand alkali-soluble forms. Liming prevented also in these samples the accumulation of the mineralized phosphorus as the alkali-soluble form, and it kept the acid-soluble fraction from decreasing.

An attempt to calculate on the basis of the results obtained the amounts of fertilizer phosphorus in various fractions could not, of course, lead to very reliable results. It seemed that incubation with or without lime did not change the distribution of the "superphosphate-phosphorus" which mainly occurred in the fractions extractable by ammonium fluoride or sodium hydroxide. The incubation without lime appears to have reduced the acid-soluble fraction of hyperphosphate phosphorus and caused some increase in the fluoride-soluble forms.

The phosphorus test values obtained by the extraction with $0.03 \mathrm{~N} \mathrm{NH}_{4} \mathrm{~F}-$ $0.025 \mathrm{~N} \mathrm{HCl}$ were in accordance with the picture found by the fractionations. If 
these values are supposed to indicate the availability of phosphorus to plants, it must be concluded that liming did not in any case improve the availability more than the incubation did. The test values for acetic acid soluble phosphorus proved to be rather worthless as the indicator of the phosphorus conditions of the present soil samples.

The results of these experiments are mostly in accordance with what has been previously published $(4,7,10,11)$. Only the complete failure of liming to increase the mineralization of organic phosphorus was somewhat surprising. Also the apparent accumulation of mineralized organic phosphorus into the ammonium-fluoride soluble fraction in the limed soils deserves attention. It may be taken to indicate either that aluminium oxide and hydroxide is able to bind phosphate also in the presence of calcium carbonate, or that this fraction may contain e.g. dicalcium phosphate.

\section{$S u m m$ ary}

Samples from two field trials were incubated at $20^{\circ} \mathrm{C}$ for seven months with or without an addition of 1 per cent $\mathrm{CaCO}_{3}$. Both the samples of loam soil and silt soil originated from the surface inch of plots treated with no phosphate, superphosphate or hyperphosphate, resp.

It was found that liming did not in any case increase the amount of organic phosphorus mineralized during the incubation. Its effect was observed in the distribution of this phosphorus in the various fractions of inorganic phosphorus. In the distinctly acid samples which were incubated without lime the mineralized phosphorus seemed to accumulate as the ammonium fluoride-soluble and alkali-soluble forms, while in the neutral samples incubated with lime an increase only in the former fraction was detected. When the samples from the hyperphosphate plots were incubated without lime, apparently some apatite of the fertilizer was dissolved and sorbed as the ammonium fluoride soluble or alkali-soluble forms. No decrease in the acid-soluble fraction of these samples incubated with lime did occur.

\section{REFERENCES}

(1) Askinasi, D. L. \& Jarussow, S. S. 1930. Kalkung als Faktor der Phosphorsäuremobilisation in Podsolböden. Zeitschr. f. Pflanzenern. Düng. u. Bodenk. A 15: 218-233.

(2) Aung Khin \& Leeper, G. W. 1960. Modifications in Chang and Jackson's procedure for fractionating soil phosphorus. Agrochimica IV: 246-254.

(3) Chang, S. C. \& Jackson, M. L. 1957. Fractionation of soil phosphorus. Soil Sci. 84: 133-144.

(4) - - - - 1958. Soil phosphorus fractions in some representative soils. J. Soil Sci. 9: 109-119.

(5) FIFE, C. V. 1959. An evaluation of ammonium fluoride as a selective extractant for aluminum-bound soil phosphate: II. Preliminary studies on soils. Soil Sci 87: 83-88.

(6) Ghani, M. O. \& Aleem, S. A. 1942. Effect of liming on the transformation of phosphorus in acid soils. Indian J. Agric. Sci. 12: 873-882.

(7) Hsv, P. H. \& Jackson, M. L. 1960. Inorganic phosphate transformations by chemical weathering in soils as influenced by $\mathrm{pH}$. Soil Sci. 90 : $16-24$. 
(8) Hännınen, P. \& KaIlA, A. 1960 Field trials on the store dressing with rock phosphate. J. Sci. Agr. Soc. Finland 32: 107-117.

(9) KanlA, A. 1961. Fertilizer phosphorus in some Finnish soils. Ibid 33: 131-139.

(10) Laverty, J. C. \& Mclean. E, O. 1961. Factors affecting yields and uptake of phosphorus by different crops: 3 . Kinds of phosphate - native, applied, and formed. Soil Sci. 91: 166-171

(11) Pratt, P. F. \& Shoemaker, H. E. 1955. Acid- and alkali-soluble phosphorus in relation to soil reaction. Ibid $80: 381-389$.

(12) Rathje, W. 1942. Zur Kenntnis der Phosphate. IV. Mitteilung: Das Phosphat-Gleichgewicht im Boden. Bodenk. u. Pflanzenern. 28: 129-159.

(13) Sauerlandt, W. 1936. Untersuchungen über die Salpeterbildung und die Umsetzungen der Phosphorsäure unter dem Einfluss von Kalkdüngung und dem Kalkgehalt der Böden. Zeitschr. f. Pflanzenern. Düng. u. Bodenk. 45: 129-153.

S E L O S T U S

\section{MUHITUKSEN JA KALKITUKSEN VAIKUTUKSESTA MAAN FOSFORIIN}

Armi Kaila

Yliopiston maanviljelyskemian laitos, Helsinki

Tutkimuksessa selostetaan kahden superfosfaatin ja hienofosfaatin vertailukokeen maanäytteiden muhituksessa saatuja tuloksia. Todettiin, ettei kalkitus kummassakaan maassa lisännyt muhituksessa mineraloituvan orgaanisen fosforin määrää. Sen sijaan se vaikutti tämän fosforin sitoutumismuotoon: kun kalkitsematta muhitetuissa ja selvästi happamissa näytteissä vapautuva fosfori lisäsi sekä ammoniumfluoridiin että emäkseen liukenevaa fosforia, kalkituissa näytteissä havaittiin vain edellisen fraktion kasvaneen. Hienofosfaattiruutujen näytteitä muhitettaessa ilman kalkkia liukeni ilmeisesti lannoitteen apatiittia, joka pidättyi ammoniumfluoridiin ja emäkseen liukenevana fosforina. Kalkituissa näytteissä ei havaittu happoonliukenevan fraktion pienentyvän. 